\title{
ISOLASI DAN PENENTUAN KADAR MINYAK NILAM (Pogostemon cablin Benth) ASAL PEUNARON ACEH TIMUR MENGGUNAKAN GC-MS
}

\author{
Ela Daniati*1, Mastura ${ }^{2}$ dan Hasby $^{3}$ \\ ${ }^{1,2,3}$ Program Studi Pendidikan Kimia, FKIP Universitas Samudra \\ Jln. Kampus Meurandeh, Langsa 24416 \\ *E-mail: eladaniati01@gmail.com
}

\begin{abstract}
Abstrak
Penelitian ini bertujuan untuk mengetahui hasil isolasi minyak nilam dari daun nilam asal Peunaron Kabupaten Aceh Timur serta menentukan kualitas yang ada pada minyak nilam dan untuk mengetahui kadar yang terdapat pada minyak nilam. Analisis hasil data penelitian dideskripsikan menggunakan analisis kuantitatif dan deskriptif. Berdasarkan penelitian yang telah dilakukan bahwa hasil isolasi minyak nilam asal Peunaron Kabupaten Aceh Timur, menghasilkan nilai rendemen sebesar 2,04\%. Kualitas minyak nilam yang diperoleh menunjukkan hasil berwarna kuning dengan nilai berat jenis sebesar 0,950 yang sudah memenuhi standar SNI. Penentuan indeks bias menghasilkan nilai sebesar 1,50339 dengan hasil yang belum memenuhi standar SNI dan kadar minyak nilam yang dihasilkan sebanyak 33 komponen senyawa kimia dengan komponen utama kadar Patchouli alcohol sebesar 3,65\%. Maka dapat disimpulkan bahwa minyak nilam asal Peunaron Kabupaten Aceh Timur masih belum memenuhi standar SNI.
\end{abstract}

Kata kunci: Minyak Nilam (Pogostemon cablin Benth), GC-MS, Peunaron Aceh Timur

\begin{abstract}
This study aims to determine the result of isolation of patchouli oil from Peunaron East Aceh and determine the quality of patchouli oil and to determine the levels contained in patchouli oil. Analysis of the results of the research data is described using quantitative and descriptive analysis. Based on research that has been done that the results of isolation of patchouli oil from Peunaron, East Aceh Regency, yields a value of 2,04\%. Patchouli oil quality obtained shows yellow results with a specific gravity value of 0,950 that meets SNI standards. The determine of the refractive index produces a value of 1,50039 with results that do not meet SNI standards and the resulting patchouli oil content is 33 chemical compound components with the main component of patchouli alcohol content of 3,65\%. It can be concluded that patchouli oil from Peunaron, East Aceh Regency still does not meet SNI standards.
\end{abstract}

Keywords: Patchouli oil (Pogostemon cablin Benth), GC-MS, East Aceh Peunaron.

\section{PENDAHULUAN}

Indonesia merupakan bagian dari negara yang memproduksi minyak atsiri yang berperan penting di dunia sebagai penyumbang devisa lebih dari $50 \%$ total ekspor minyak atsiri (Hariyani, Widaryanto \& Herlina, 2015, h. 205). Saat ini di pasar dunia terdapat 70 jenis minyak astiri yang telah diperdagangkan. Sementara itu, 
Indonesia memiliki sekitar 40 jenis tanaman yang menghasilkan minyak atsiri yaitu salah satunya tanaman nilam. (Idris, Jura \& Said, 2014, h. 301). Indonesia juga berperan sebagai pemasok minyak nilam terbesar dengan kontribusi 90\% (Setya, Budiarti \& Mahfud, 2012, h. 25). Tanaman nilam merupakan tanaman herba (semak) dan termasuk kedalam family Labiatae. Minyak nilam adalah minyak atsiri yang diperoleh dari tanaman nilam (Idris, Jura \& Said, 2014, h. 302).

Tanaman nilam mengandung minyak atsiri yang berbeda pada setiap bagian tubuh tanaman. Akar dan batang tanaman nilam mengandung rendemen minyak yang sedikit dengan nilai sekitar 0,5-0,7\% namun menghasilkan mutu minyak terbaik dengan kadar Patchouli alcohol diatas 40\%. (Hariyani, Widaryanto \& Herlina, 2015, h. 206).

Minyak nilam memiliki berbagai macam kegunaan baik dibidang industri maupun kesehatan. Dibidang industri minyak nilam berfungsi sebagai bahan sabun, kosmetik dan bahan industri parfum (Idris, Jura \& Said, 2014, h. 302). Sedangkan dalam bidang farmasi minyak nilam dimanfaatkan sebagai obat-obatan (Harimurti, Soerawidjaja, Sumangat \& Risfaheri, 2012, h. 1). Minyak nilam juga dapat dimanfaatkan sebagai obat tradisional yakni sebagai obat penyembuh luka, obat penurun panas dan dapat menghilangkan bekas luka (Kusuma \& Mahfud, 2017, h. 1525).

Minyak nilam dapat diproduksi melalui metode destilasi. Destilasi adalah salah satu bagian dari isolasi minyak atsiri yang paling sering digunakan. Metode destilasi ini terbagi menjadi tiga jenis, yaitu destilasi air, destilasi uap dan destilasi uap dan air. (Sulaiman, \& Harsono, 2012, h. 16). Penelitian ini menggunakan destilasi uap dan air. Minyak yang didapatkan dari hasil destilasi kemudian ditimbang beratnya selanjutnya dibagi dengan berat bahan kering untuk memperoleh nilai rendemen. Adapun untuk mengetahui mutu/kualitas minyak nilam yang telah didestilasi, maka ditentukan warna, berat jenis, dan indeks biasnya. Analisis mutu ini sesuai dengan Standar Nasional Indonesia (SNI) 06-2385-2006, sedangkan untuk mengetahui kadar senyawa kimia minyak nilam dilakukan dengan menggunakan alat GC-MS.

Proses produksi pengolahan minyak atsiri dari tanaman nilam yang dikembangkan oleh petani di Kecamatan Peunaron Kabupaten Aceh Timur belum diketahui nilai rendemennya. Hal ini dikarenakan, belum ada yang melakukan penelitian tentang minyak nilam yang terdapat di Kecamatan Peunaron Kabupaten Aceh Timur. Berdasarkan penelitian di Subang Jawa Barat, dtemukan hasil bahwa evaluasi proses ekstraksi minyak nilam dengan teknik hidrodifusi yang dilakukan di Subang Jawa Barat menghasilkan mutu minyak nilam dengan kadar Patchouli alcohol sebesar 29,66\% (Harimurti, Soerawidjaja, Sumangat \& Risfaheri, 2012, h. 9)

Perbedaan asal sampel dan metode destilasi yang digunakan diduga dapat mempengaruhi senyawa kimia yang terkandung dari suatu tumbuhan, Sehingga senyawa yang dihasilkan akan berbeda dan tidak menutup kemungkinan juga bahwasanya hasil senyawa yang diperoleh akan sama seperti yang telah dilaporkan sebelumnya. Berdasarkan uraian di atas, peneliti tertarik untuk melakukan penelitian dengan judul "Isolasi dan Penentuan Kadar Minyak Nilam (Pogostemon cablin Benth) Asal Peunaron Aceh Timur Menggunakan GC-MS". 


\section{METODE PENELITIAN}

Data penelitian ini diselesaikan dengan menggunakan data teknik analisis kuantitatif dan deskriptif. Teknik analisis kuantitatif merupakan analisis menggunakan angka, mulai dari pengumpulan data, serta hasil yang diperoleh. Deskripsi digunakan untuk menggambarkan suatu data yang telah terkumpul sebelumnya.

\section{Alat dan Bahan}

Adapun alat yang digunakan yakni satu set alat destilasi, erlenmeyer, gelas kimia, blender, tabung reaksi, pipet tetes, piknometer, refraktometer dan instrument GC-MS. Bahan yang digunakan yaitu daun nilam yang diperoleh dari Kecamatan Peunaron Kabupaten Aceh Timur, etanol $96 \%\left(\mathrm{C}_{2} \mathrm{H}_{5} \mathrm{OH}\right)$, asam klorida $(\mathrm{HCl}) 2 \mathrm{~N}$, pita magnesium $(\mathrm{Mg})$, kalium hidroksida $(\mathrm{KOH})$, pereaksi dragendroff, pereaksi mayer, pereaksi wagner, pereaksi Libermann Burchard, besi (III) klorida $\left(\mathrm{FeCl}_{3}\right) 1 \%$, besi (III) klorida $\left(\mathrm{FeCl}_{3}\right) 5 \%$, natrium sulfat $\left(\mathrm{Na}_{2} \mathrm{SO}_{4}\right)$ anhidrat.

\section{Prosedur Kerja}

\section{Uji Isolasi Minyak Nilam}

a. Preparasi sampel

Sampel daun nilam yang diperoleh dari Kecamatan Peunaron Kabupaten Aceh Timur terlebih dahulu dibersihkan, kemudian dijemur dengan cara dianginanginkan hingga kering. Sampel yang telah dijemur kemudian dihaluskan menggunakan blender. Pengeringan dilakukan untuk menghilangkan kadar air yang terkandung didalam sampel daun nilam, sedangkan proses penghalusan dilakukan untuk meningkatkan luas permukaan interaksi antara pelarut dengan sampel daun nilam sehingga pelarut dapat mengekstrak/mengeluarkan metabolit sekunder (Muharrami, Munawaroh, Ersam \& Santoso, 2017, h. 126)

b. Maserasi sampel

Sebanyak 100 g serbuk sampel daun nilam dimasukkan kedalam gelas kimia dimaserasi dengan $400 \mathrm{~mL}$ pelarut etanol 96\%. Rendam selama satu hari aatau 24 jam lalu disaring dengan kertas saring dan diambil filtratnya (Suzery, Lestari \& Cahyono, 2010, h. 2).

c. Skrining Fitokimia

Uji alkaloid: Sebanyak $2 \mathrm{~mL}$ ekstrak daun nilam dimasukkan kedalam tiga tabung reaksi, masing-masing tabung ditambahkan pereaksi dragendroff, pereaksi wagner dan pereaksi mayer. Terbentuknya endapan menunjukkan bahwa daun nilam mengandung senyawa alkaloid (Sangi, Runtuwene, Simbala \& Makang, 2008, h. 48).

Uji flavonoid: Sebanyak $2 \mathrm{~mL}$ ekstrak daun nilam dimasukkan kedalam gelas kimia dan ditambahkan aquades dan sampai mendidih selama 5 menit. Setelah itu, disaring dan filtratnya digunakan sebagai larutan uji. Filtrat dimasukkan kedalam tabung reaksi lalu ditambahkan pita $\mathrm{Mg}$ dan $2 \mathrm{ml} \mathrm{HCl}$ pekat kemudian dikocok dengan kuat (Nugrahani, Andayani \& Hakim, 2016, h. 98).

Uji fenolik: Sebanyak $2 \mathrm{~mL}$ ekstrak daun nilam dilarutkan dengan $2 \mathrm{~mL} \mathrm{FeCl}_{3} 1 \%$. Prubahan warna hijau, merah ungu, biru atau hitam kuat menunjukkan adanya senyawa fenolik (Kayadoe, Fadli, Hasim \& Tomasoa, 2015, h. 90).

Uji tanin: Sebanyak $1 \mathrm{~mL}$ ekstrak daun nilam ditambahkan sedikit tetes $\mathrm{FeCl}_{3} 1 \%$. Amati perubahan yang terjadi, hasil positif ditandai dengan perubahan warna menjadi hijau kecoklatan atau warna hitam biru (Kayadoe, Fadli, Hasim \& Tomasoa, 2015, h. 91).

Uji saponin; Sebanyak $2 \mathrm{~mL}$ ekstrak daun nilam dilarutkan dalam aquades ditanbah 10 
tetes $\mathrm{KOH}$ dan dipanaskan selama 5 menit kemudian dikocok selama 15 menit. Hasil positif ditunjukkan dengan terbentuknya busa stabil selama 15 menit (Ningsih, Zusfahair, \& Kartika, 2016, 104).

Uji Polifenol: Sebanyak $2 \mathrm{~mL}$ ekstrak daun nilam dilarutkan dalam aquades $10 \mathrm{~mL}$, dipanaskan selama 5 menit kemudian disaring. Tambahkan 4-5 tetes $\mathrm{Fecl}_{3} 5 \%$ pada filtrat yang terbentuk. Perubahan warna menjadi biru tua atau hijau kehitaman menunjukkan adanya senyawa polifenol (Ningsih, Zusfahair \& Kartika, 2016, h. 105). Uji terpenoid: Uji terpenoid dilakukan dengan melarutkan sampel daun nilam sebanyak $2 \mathrm{~mL}$ dengan pereaksi Libermann Burchard (asam asetat anhidrat dan asam sulfat pekat) sebanyak $1 \mathrm{~mL}$. Sampel yang mengandung senyawa terpenoid akan menghasilkan perubahan warna membentuk cincin coklat atau violet (Andriyanto, Ardiningsih \& Idiawati, 2016, h. 10)

d. Destilasi

Tanaman nilam yang telah dikeringkan sebanyak $1,5 \mathrm{Kg}$ dimasukkan kedalam alat destilasi dengan air pada suhu $100^{\circ} \mathrm{C}$ hingga diperoleh distilat. Distilat selanjutnya dimasukkan kedalam corong pisah untuk memisahkan lapisan air dan minyak. Minyak yang mengandung air lalu dikeringkan dengan menambahkan serbuk senyawa natrium sulfat $\left(\mathrm{Na}_{2} \mathrm{SO}_{4}\right)$ anhidrat. Setelah itu di lakukan penyaringan sehinggga diperoleh minyak nilam bebas aiir (Muharam, Yuningsih \& Rohana, 2017, h. 117).

\section{Uji Kualitas Minyak Nilam}

a. Penentuan warna

Pipet $10 \mathrm{~mL}$ minyak nilam kemudian dimasukkan kedalam tabung reaksi, sandarkan tabung reaksi berisi minyak nilam pada kertas berwarna putih. Amati warnanya dengan mata langsung.
Penentuan rendemen minyak nilam ditentukan dengan cara membandingkan berat dari minyak nilam dengan berat sampel daun nilam. Rendemen minyak nilam berkisar antara 2-3\% (Nurhaen, Winarsi \& Ridhay, 2016, h. 151).

c. Penentuan berat jenis

Timbang Piknometeer kosong yang sudah bebas dari air menngunakan neraka analitik. Kemudian diisi piknometer dengan minyak nilam sampai tanda batas dan tidak terjadi gelembung udara lalu ditimbang. Lakukan terhadap aquades dengan cara yang sama. (Zaimah, 2014, h. 3).

d. Penentuaan indeks bias

Penentuuan indeks bias diukur menggunakkan alat refraktometer jenis Automatic Refraktomeeter Koehler-Modell K-27550. Langkah pertama yaitu dengan membersihkan prisma pada refraktometer mengggunakan larutan alkohol dan selanjutnya dikeringkan mengggunakan tisu.

e. Penentuan Kadar Minyak Nilam

Menggunakan GC- MS

Penentuan kadar minyak nilam dari daun nilam asal Peunaron Kabupaten Aceh Timur dilakukan di Laboratorium FMIPA Universitas Syiah Kuala menggunakan alat Gas Chromatographi- Mass Spectoometry (GC-MS) modell Shimadzuu QP 2010sS. kondisi analisis adalah jenis kolm Aglientj5W DB-1, panjaing kolm 30 meter, diameter kolm $0,25 \mathrm{~mm}$, suhu injgector $310^{\circ} \mathrm{C}$, tenakan $13,7 \mathrm{kpa}$, Gas pembawa Helium dengan laaju alir $0,50 \mathrm{ml} / \mathrm{menit}$. Suhu kolm terprogram dengan suhu awal $70^{\circ} \mathrm{C}$ selama 5 menit, lalu dinaikkan secara perlahan dengan kenaikan $5,0^{\circ} \mathrm{C} /$ menit sampai mencapai suhu akhir $260^{\circ} \mathrm{C}$ dan dipertahankan. Hasil pemisahhan oleh GC langsung dianalisisa dengan menggunakan MS dengan cara membanndingkan spektra fragmentasi minyak nilam denggan b. Penentuan rendemen minyak nilam 
fragmentasi standar yang terdapat dalam memori.

\section{HASIL DAN PEMBAHASAN}

\section{Hasil Isolasi Minyak Nilam}

a. Skrining Fitokimia
Uji ini bertujuan untuk memperoleh senyawwa kimia yang terdapat didalam daun nilam dengan cara skrining fitokimia. Hasil uji senyawa metabolite sekunderr pada daun nilam dapat dilihat pada tabel 1 .

Table 1. Hasil Uji Metabolite Sekunder Ekstrak Duaun Nilam

\begin{tabular}{|c|c|c|c|}
\hline Kandunggn Kima & Reagen & Hasil & Keterangan \\
\hline 1. Alkaloid & $\begin{array}{l}\text { Dragendroff } \\
\text { Wagner } \\
\text { Mayer }\end{array}$ & $\begin{array}{l}++ \\
- \\
+\end{array}$ & $\begin{array}{l}\text { Endapan berwarna jingga } \\
\text { Tidak terbentuk endapan } \\
\text { Endapan berwarna putih }\end{array}$ \\
\hline 2. Flavonoid & $\mathrm{HCl} 2 \mathrm{~N}+$ pita $\mathrm{Mg}$ & - & $\begin{array}{l}\text { Tidak terjadi perubahan } \\
\text { warna }\end{array}$ \\
\hline 3. Fenolik & $\mathrm{FeCl}_{3} 1 \%$ & +++ & $\begin{array}{l}\text { Perubahan warna menjadi } \\
\text { hitam kuat }\end{array}$ \\
\hline 4. Tanin & $\mathrm{FeCl}_{3} 1 \%$ & +++ & $\begin{array}{l}\text { Perubahan warna menjadi } \\
\text { hitam biru }\end{array}$ \\
\hline 5. Uji Saponin & Aquades $+\mathrm{KOH}$ & - & Tidak terbentuk busa \\
\hline 6. Uji Polifenol & $\begin{array}{l}\text { Aquades } \\
5 \%\end{array}$ & - & $\begin{array}{l}\text { Perubahan warna menjadi } \\
\text { coklat }\end{array}$ \\
\hline 7. Uji Terpenoid & Liberman Burchard & +++ & $\begin{array}{l}\text { Perubahan warna menjadi } \\
\text { jingga }\end{array}$ \\
\hline
\end{tabular}

Keterangan : + (sedikit), ++ (sedang), +++ (banyak), - (tidak terjadi perubahan).

\section{b. Hasil Isolasi Minyak Nilam}

Isolasi pada minyak nilam dilakukan dengan cara destilasi uap dan air, destilasi telah dilakukan selama 15 kali untuk memperoleh minyak nilam.

Pemurnian minyak nilam dilakukan sebanyak tiga kali pengulangan dan ditimbang dengan menggunakan tiga botol terpisah. Hasil dari pemurnian minyak nilam yaitu sebesar 11,2 gram, 9,4 gram dan 10 gram. Setelah dijumlahkan berat minyak nilam murni mencapai nilai sebesar 30,6 gram.

\section{Hasil Uji Kualitas Minyak Nilam}

Untuk menentukan kualitas minyak nilam dilakukan dengan beberapa cara yaitu uji penentuan warna, penentuan berat jenis dan penentuan indeks bias. Hasil uji kualitas minyak nilam dapat dilihat pada table 2 .

Tabel 2. Hasil Uji Kualitas Minyakk Nilm

\begin{tabular}{|l|l|c|c|}
\hline No & $\begin{array}{c}\text { Jenis } \\
\text { Uji }\end{array}$ & $\begin{array}{c}\text { Persyaratan } \\
\text { (SNI 0 6- } \\
\text { 2385-2006) }\end{array}$ & $\begin{array}{c}\text { Hasil } \\
\text { minyak } \\
\text { nilam }\end{array}$ \\
\hline 1 & Warnaa & $\begin{array}{c}\text { Kuning muda- } \\
\text { coklat } \\
\text { kemerahan }\end{array}$ & Kuning \\
\hline 2 & $\begin{array}{l}\text { Berat } \\
\text { jenis }\end{array}$ & $0,950-0,975$ & 0,950 \\
\hline 3 & $\begin{array}{l}\text { Indeks } \\
\text { bias }\end{array}$ & $1,507-1,515$ & 1,50339 \\
\hline
\end{tabular}


3. Penentuan Kadar Minyak Nilam Menggunakan GC-MS

Berdasarkan hasil analisis dengan menggunakan GC-MS diperoleh komponen-komponen senyawa kimia yang terkandung didalam minyak nilam asal Peunaron Kabupaten Aceh Timur. Hasil kromatogram komponen minyak nilam dapat dilihat pada Gambar 1.

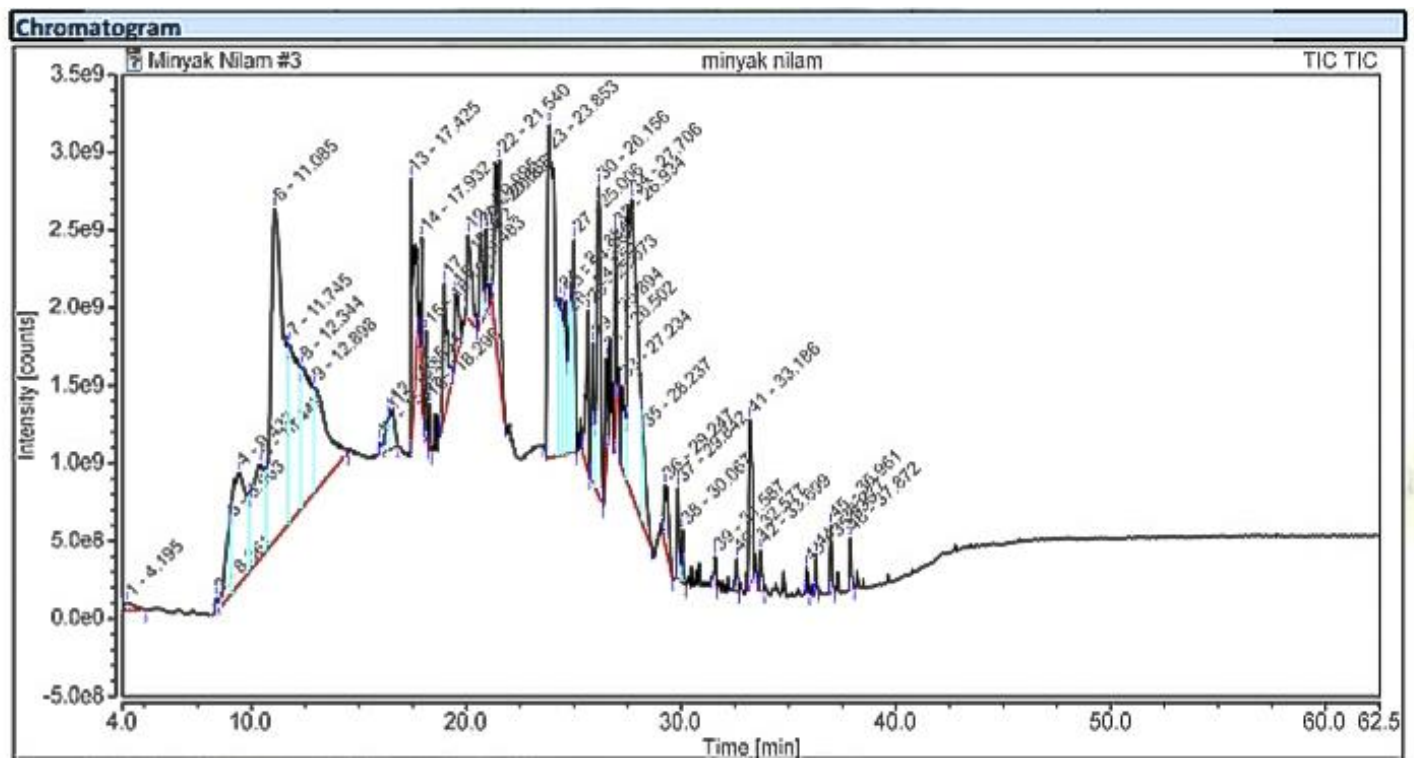

Gambar 1. Kromatogram Minyak Nilam Asal Peunaron Kabupaten Aceh Timur (Sumber: Dokumentasi Penelitian)

Berdasarkan Gambar 1 dapat dilihat bahwa terdapat 33 jenis komponen senyawa kimia yang terkandung di dalam minyak nilam. Komponen senyawa minyak nilam yangg dianalisis menggunakan alat Gas Chromatography-Mass Spectometry (GC-MS) dapat diliihat pada tabel 3.

Tablel 3. Komposisi Senyawa Kimia Minyakk Nilam

\begin{tabular}{|c|l|l|c|}
\hline $\begin{array}{r}\text { Peak } \\
\text { No. }\end{array}$ & $\begin{array}{l}\text { Waktu } \\
\text { Retensi }\end{array}$ & \multicolumn{1}{|c|}{ Komponen } & $\begin{array}{c}\text { Area } \\
\text { \% }\end{array}$ \\
\hline 1. & 4.19 & B-Pinene & 0.26 \\
2. & 8.36 & 3-Octanol & 0.14 \\
3. & 8.96 & 4,7-Methanoazulene, 1,2,3,4,5,6,7,8- & 1.38 \\
4. & 9.43 & 1H-Cyclopropa[a]naphthalene, decahdydro- & 5.53 \\
5. & 10.45 & 1H-Cyclopropa[a]naphthalene, decahdydro- & 4.45 \\
$\mathbf{6 .}$ & $\mathbf{1 6 . 5 3}$ & $\boldsymbol{\alpha}$-Guaiene & $\mathbf{2 8 . 8 7}$ \\
7. & 17.42 & B-Gguaiene & 2.52 \\
8. & 17.93 & (E)-2-(8R,8as)-8,8a-diimethyl-3,4,6,7,8,8a & 0.65 \\
9. & 18.12 & 2R,8R,8aS-8,8a-dimethyl-2 & 0.42 \\
10. & 18.97 & Ledene oxide-(ii) & 1.92 \\
11. & 20.09 & Carryophillen oxide & 1.35 \\
12. & 20.66 & 1-Oxaspiro (2,5)octane, 5,5-dimethyl & 1.12 \\
$\mathbf{1 3 .}$ & $\mathbf{2 1 . 5 4}$ & Patchouli alcohol & $\mathbf{3 . 6 5}$ \\
\hline
\end{tabular}




\begin{tabular}{|r|l|l|c|}
\hline $\begin{array}{r}\text { Peak } \\
\text { No. }\end{array}$ & $\begin{array}{l}\text { Waktu } \\
\text { Retensi }\end{array}$ & \multicolumn{1}{|c|}{ Komponen } & $\begin{array}{c}\text { Area } \\
\text { \% }\end{array}$ \\
\hline 14. & 23.85 & 1,4-dimethyl-7-prop-1-en-2 & 8.64 \\
15. & 24.75 & Calarene epoxide & 1.69 \\
16. & 25.01 & Alloaromadendrene epoxide-(1) & 2.28 \\
17. & 25.67 & Issoaromadendrene epoxide & 6.46 \\
18. & 25.89 & 2-(2R,4aR,8aS)-4a-Methyll & 1.33 \\
19. & 26.16 & (-)-Globulol & 3.90 \\
20. & 26.50 & Aromadendrene oxide & 0.86 \\
21. & 26.93 & Bicycle (4,4,0)ec-2-ene-4-ol & 1.28 \\
$\mathbf{2 2 .}$ & $\mathbf{2 7 . 2 3}$ & 4-Hidroxy-6-Methyl-3(4-methylpenttanoyl)-2H-pyran-2- & $\mathbf{1 1 . 3 2}$ \\
23. & 28.24 & one & 1.42 \\
24. & 29.25 & 1Ar-(1alpha,sabeta,9ar)-5a,9,9-trimethyloctahidrobenzo & 0.99 \\
25. & 29.84 & 1-Heptatriacotanol & 0.62 \\
26. & 30.07 & Phytol & 0.60 \\
27. & 31.59 & Corymbolon & 0.22 \\
28. & 32.58 & 5-Benzoofuranacetic acidf, 6-etthenyll-2,5,6,7 & 0.23 \\
29. & 33.19 & 2-Buteneal, 2-methyl-4(2,6,6-trimethyl-1-cyclohexen-1-yl) & 1.87 \\
30. & 35.84 & n-hexadecanoic acid & 0.15 \\
31. & 36.28 & 1,6,10,14,18,22-tertacosahexaen-3-ol & 0.14 \\
32. & 36.96 & Trans-13-octadecenoic acid & 0.34 \\
33. & 37.87 & 9(E),11(E)-conjugatedlinoleic acid & 0.29 \\
& & 9,12,15-Octadecattrienoic acide & \\
\hline
\end{tabular}

\section{KESIMPULAN}

Berdasarkan penelitian tentang isolasi dan penentuan kadar minyak nilam (Pogostemon cablin Benth) asal Peunaron Kabupaten Aceh Timur menggunakan GCMS maka penulis mengambil kesimpulan yaitu isolasi minyak nilam dari daun nilam asal Peunaron Kabupaten Aceh Timur menghasilkan nilai rendemen sebesar $2,04 \%$.

Kualitas minyak nilam asal Peunaron Kabupaten Aceh Timur ditentukan melalui beberapa uji, yaitu uji warna, penentuan berat jenis dan penentuan indeks bias. Uji warna pada minyak nilam menunjukkan hasil berwarna kuning dan sudah memenuhi kategori standar mutu (SNI: kuning-coklat kemerahan). Penentuan berat jenis menghasilkan nilai sebesar 0,950 maka nilai berat jenis minyak nilam sudah memenuhi standar (SNI: 0,950-0,975). Penentuan indeks bias menghasilkan nilai sebesar 1,50339, jika dibandingkan dengan standar mutu, maka hasil yang diperoleh belum memenuhi persyaratan (SNI: 1,507-1,515).

Kadar kimia minyak nilam yang diperoleh dari Peunaron Kabupaten Aceh Timur menghasilkan sebanyak 33 komponen senyawa kimia. Senyawa yang berperan sebagai komponen pendukung minyak nilam memiliki kadar yaitu $\alpha$ Guaiene (28.87\%), Patcjhouli alcohol (3.65\%) dan 4-Hidroxy-6-Methhyl-3(4methylpenntanoyl)-2H-pyraan-2-oone

(11.32\%). Dengan demikian kadar kimia Patchouli alcohol masih belum memenuhi persyaratan SNI.

\section{DAFTAR PUSTAKA}

Andriyanto , B. E., Ardiningsih, P., \& Idiawati, N. (2016). Skriningg Fitkomia Ekstrak Daun Belimbing Hutan (Baccaurea angulat Merr). $J K K, 5(4), 9-13$. 
Harimurti , N., Soerawidjajja, T.H., Sumangatt., \& Risfaheri. (2012). Ekstraksi Minyak Nilam (Pogostemon cablin Benth) Dengan Teknik Hidrodifusii Pada Tekanan 1-3 Bar. Jurnal Pasccapanen, 9(1), 1-10.

Hariyani., Widaryanto, E., \& Herlinaa, N. (2015). Pengaruh Umurr Panen Terhadap Rendmen dn Kwalitas Minyak Astiri Tanamann Nilam (Pogostemon cablin Bentth). Journal Produksi Tanamann, 3(3), 205-211.

Idris, A., Jura, M.R., \& Said, I. (2014). Analisis Kualitas Minyak Nilam (Pogostemon cablin Benth) Produksi Kabupaten Buol. Jurnal Akademika Kimia, 3(2), 301-308.

Kayadoe, V., Fadli, M., Hasim, R., \& Tomasoa, M. (2015). Ekstrak Daun Pandan (Pandanus amarylifous Roxb) Sebagai Inhibitor Korosi Baja SS-304 Dalam Larutan $\mathrm{H}_{2} \mathrm{SO}_{4}$. Molekul, 10(2), 88-96.

Kusuma, H.S., \& Mahfud, M. (2017). GCMS Analysis of Essential Oil of Pogostemon cablin Growing in Indonesia Extracted by Microwaveassisted Hydrodistillation. International Food Research Journal, 24(4), 1525-1528.

Muharam, S., Yuningsih, L. M., \& Rohana, I. S. (2017). Peningkatan Kualitas Minyak Nilam (Pogostemon cablin Benth) Menggunakan Kombinasi Metode Fermentasi, Delignifikasi dan Destilasi. Jurnal Kimia VALENSI: Jurnal Penelitian dna Pengembangan Ilmu Kimia, 3(2), 116-121.

Muharrami, L. K., Munawaroh, F., Ersam, T., \& Santoso, M. (2017).
Inventarisasi Tumbuhan Jamu dan Skrining Fitokimia Kabupaten Sampang. Jurnal Pena Sains, 4(2), $1-9$.

Ningsihh, D. R., Zusfahaiir., \& Kartikia, D. (2016). Identifikisi Senyawa MEtabolite Sekunderer Serta Uji Aktivitas Ekstrak Daon Sirsak Sebagi Anti baktery. Molekul, 11(1), 101-111.

Nugrahani, R., Andayani, Y., \& Hakim, A. (2016). Skriningg Fitokima daru Eksetrak Buah Bunciss (Phaseolus vulgaris L) Dalam Sediaaan Serbuk . Journal Penelitian Pendidikan IPA, 2(1), 1-8.

Nurhaen., Winasi, D., \& Ridhay, A. (2016). Isollasi dan Identivikasi Kima Minyak astri dari Daonn, Batang dan Bunga Tumbuhan Salembagi (Mellisa sp). Online jurnla of Natural Science, 5(2), 149-157.

Sangi, M., Runtuwene, M. R. J., Simbala, H. E. I., \& Makang, V. M. A. (2008). Analisis Fitokimia Tumbuhan Obat di Kabupaten Minahasa Utara. Chem. Prog, 1(1), 1-7.

Setya, N., Budiarti, A., \& Mahfud. (2012). Proses Pengambilan Minyak Atsiri Dari Daun Nilam Dengan Pemanfaatan Gelombang Mikro (MicrowaveI). Jurnal Teknik ITS, 1(1), 1-5.

Sulaiman, A., \& Harsono, D. (2012). Pengaruh Lama Penyulingan dan Komposisi Bahan Baku Terhadap Rendemen dan Mutu Minyak Atsiri dari Daun dan Batang Nilam (Pogostemon cablin Benth). Jurnal Riset Industri Hasil Hutan, 4(2), 1621. 
Suzery, M., Lestari, S., \& Cahyono, B. (2010). Penentuan Total Antosianin dari Kelopak Bunga Rosela (Hibiscus sabdariffa L) Dengan Maserasi dan Sokhletasi. Jurnal Sains \& Matematika, 18(1), 1-6.
Wijaya, H., Novitasari., Jubaidah, S. Perbandingan Metode Ekstraksi Terhadap Rendemen Ekstrak Daun Rambai Laut (Sonneratia caseolaris L. Engl). Jurnal Ilmiah Manuntung, 4(1), 79-83. 